\title{
Chlamydia trachomatis DNA Measurement
}

National Cancer Institute

\section{Source}

National Cancer Institute. Chlamydia trachomatis DNA Measurement. NCI Thesaurus.

Code C161392.

The determination of the amount of Chlamydia trachomatis DNA present in a sample. 